\title{
Study on the Strategy of Urban Small Public Space Planning Based on the Concept of Park City-Take the Old Town of Jiangling County in Jingzhou as an Example
}

\author{
Xinzhi Fei*, Bin Mao \\ School of Urban Design, Wuhan University, Wuhan, China \\ Email: ^2315823250@qq.com
}

How to cite this paper: Fei, X. Z., \& Mao, B. (2020). Study on the Strategy of Urban Small Public Space Planning Based on the Concept of Park City-Take the Old Town of Jiangling County in Jingzhou as an Example. Current Urban Studies, 8, 107-114. https://doi.org/10.4236/cus.2020.81004

Received: February 17, 2020

Accepted: March 9, 2020

Published: March 12, 2020

Copyright $\odot 2020$ by author(s) and Scientific Research Publishing Inc. This work is licensed under the Creative Commons Attribution International License (CC BY 4.0).

http://creativecommons.org/licenses/by/4.0/

\begin{abstract}
Urban small public space is a type of urban public space, which has the characteristics of a large number and wide distribution. In recent years, the urban renewal and transformation work around the improvement of the environmental quality of the city's small public space has been carried out in various cities and achieved good results. In this context, the research on small public space planning is becoming more and more abundant. Based on the concept of "park city", the article takes the existing problems in the planning and construction of urban small public space in China at this stage as the starting point and studies the planning strategy of urban small public space in the case of small public space repair in Jiangling County, Jingzhou City, Hubei Province.
\end{abstract}

\section{Keywords}

Small Public Space, Planning Strategy, Jiangling County Old Town

\section{Introduction}

As a kind of public space with the largest number and close relationship with citizens in the city public space, the improvement of space vitality and the improvement of environmental quality have become the key contents of urban renewal. In China, there are a lot of researches on small public space planning, but researches on small public planning under the guidance of urban development concept are less. As a new concept of urban development, the concept of "park city" advocates the integration of public space and natural ecology, which has a 
strong guiding significance for the construction of urban small public space. Based on the concept of park city, this paper analyzes and summarizes the current situation of the city's small public space, studying the planning strategy of urban small public space by taking the planning of small public space in Jiangling County, Jingzhou City, Hubei Province, as a practical case, hoping providing more theoretical and practical experience for the planning and construction of urban small public space.

\section{A Review of the Definition and Research of the Small Public Space in the Cities}

\subsection{The Definition of Urban Small Public Space}

Small public space is one type of urban public space. The study of the definition of small public spaces began with the definition of "pocket parks" proposed at an exhibition organized by the New York Parks Association in 1963. Pocket Parks cover an area between 400 and 7000 square meters and were built to serve residents of high-density urban centre. After pocket parks built, the transformation of small urban squares, small traffic nodes, small green spaces and other small public spaces has been incorporated into the urban renewal and transformation of the work content. In order to regulate the construction of these small public spaces, the relevant domestic authorities have formulated relevant technical norms and made specific requirements for the scale of community parks and street green space.

Based on the existing theoretical and practical basis, this study defines the small public space as a type of public space with an area of $300-10,000$ square meters, which is dominated by rest facilities, lighting facilities, small-scale buildings and structures. Small public space pays more attention to the care of urban residents, and it is also a kind of small public space which can provide communication and interaction, entertainment and leisure or rest services for citizens.

\subsection{Summary of Small Public Space Research}

Chen Shaopeng used the GIS platform to carry out buffer analysis, accessibility analysis and network analysis of the current situation of Small public space in cities and the location-based but not built-up small public space points, and the results of the analysis were used to screen reasonable small public space points to ensure the scientific nature of small public space location (Chen, 2017). On the basis of analyzing and summarizing the construction status and work focus of the city's small public space, Dong Hexuan puts forward the principle of small public space planning of "embedding, patching and crowd-regulating" (Dong et al., 2018). Song Xiaojie summarizes the problems in the management of small public space in China at this stage and puts forward the corresponding planning and control strategy for the problem (Song et al., 2017). Peng Zhenghong established the method of urban small public space planning under the guidance of 
data to enhance the scientific nature of urban small public space layout (Peng et al., 2018). Cao Yanxuan studies from the five-sense experience of people, pay attention to the vitality of small public space design (Cao, 2018). The research on urban small public space focuses on the five aspects including small public space location, small public space planning principle, small public space planning method, small public space planning management measures and humanized design of space.

\section{Basic Theory of Small Public Space}

In terms of the perception of urban space, Hillier argues that space is not the background to people's activities, but a part of our activities (Hillier, 2008). Space is an intrinsic attribute of human behavior; people moving in space, choosing the route of passage, and communicating with others in space are all influenced by the characteristics of space. Luyuan yixin made a quantitative study of the street space in the urban space, and pointed out that the place of human activity should develop to a humane environment (Luyuan, 1985). Kriel studied many types of European squares and concluded that the diversity of squares could endow the urban space with personality and characteristics (Wang, 2001).

In the study of the elements of urban spatial landscape design, F. Gilbert emphasizes that urban design is the environmental design of three-degree space, and puts forward that "urban material" and the relationship between urban material and space are also the content of urban landscape design (Gilbert, 1983). Cullen puts forward in "Simple Urban Landscape Design" that urban vision, place and urban composition are the three elements of understanding the emotional relationship between environment and human beings (Cullen, 2009). Kevin Lynch emphasizes that urban imagery is a public image formed by the overlay of individual impressions and summarizes the famous "Five Elements of Urban Image" theory (Lynch, 1983).

Combining the above theory, the author thinks that the planning of urban small public space should be based on the recognition of urban public space and the re-extraction of urban landscape design elements, with the diversity and organic of space as the planning orientation, so that the city small public space could develop more and more humane direction.

\section{The Current Situation and Existing Problems of the Construction of Small Public Space}

The construction of small public space start from the United States, the construction of the pocket park-Paley Park, the park uses falling water, tree square, garden skits and other landscape elements to enrich the park's interior space, the different materials and tones of artificial structures and natural sound elements combined, providing the noisy New York a quiet urban space and it is called the best urban space in the United States. The construction of pocket park has achieved good social and environmental benefits, which has a positive impact on 
the construction of small public space.

In our country, a lot of work also has been carried out for the transformation and renewal of small public spaces. Wuhan fully excavate and make use of the stock of public space in the main urban area, planning scattered sporadic landing in the city as "three small green space" (small squares, small green spaces, small forests), while encouraging large-scale complexes, large public buildings increasing small green space (Figure 1).

Chongqing Jiangbei District promoting the transformation content in four aspects-the small public space layout, quality, management, construction.

Nanjing planning department carrying 34 "Small renewal" project pilot work, transforming small squares, small promenades, small open spaces, with the principle of what is missing what to make up.

At present, the problems of small public space in China urban areas are concentrated in four aspects:

1) Small public space, large public space and medium-sized public space have not formed a complete system.

Large public space in cities, medium-sized public space in the city master plan or urban special planning has been identified in a good location, but the city's small public space due to the layout of scattered or small area can only be abandoned or temporarily shelved and not with large and medium-sized public space to form a complete system. For example, in Jiangling County, its master plan determines the location of large public spaces such as Longyuan Lake and Longyuan Lake Park, and determines the scope of the city's green line in the green space special planning, while small spaces like the Neijing River are not required. This actually disconnects the system of urban public spaces.

2) The quality of the built small public space is not high, not attractive.

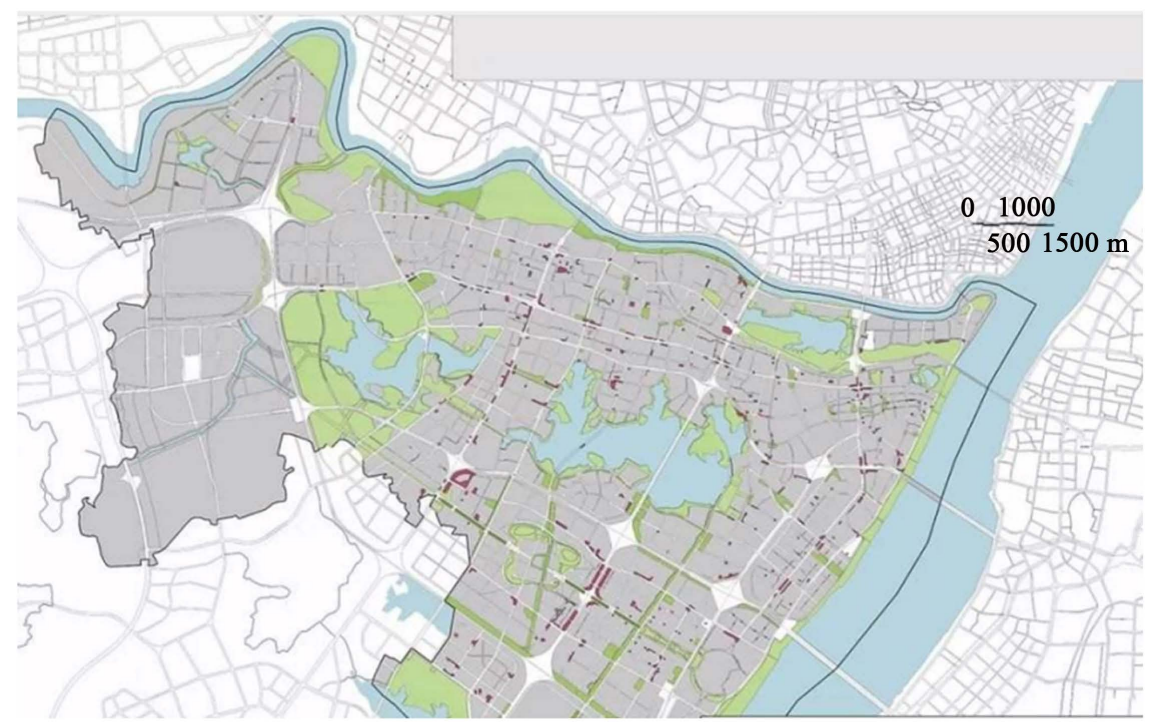

Figure 1. A miniature public space planning map in Hanyang district, Wuhan (Pictures from the Internet). 
Some of the completed small public space is often neglected by the public due to limited construction funds or lack of maintenance or unreasonable design. In fact, such a situation is also prevalent in large, medium and small cities, worthy of attention.

3) The transportation between the small public space and the surrounding residential space or traffic node is not smooth.

The correlation between the small city public space and the surrounding space is also one of the existing problems of small public space, mainly because of the low accessibility of urban traffic, especially in the urban pedestrian traffic, traffic is not smooth. Citizens often walk from their homes to small public spaces, where there may be obstacles, such as piles of garbage and unreasonable walls.

4) Part of the Small public space is privately occupied.

In some cities with water resource advantages, small public spaces along inland rivers or lakes are often encroached upon by the food fields of citizens.

\section{Small Public Space Planning Strategy Based on the Concept of Park City}

The strategy of small public space planning under the guidance of park city concept can be studied from four aspects.

\subsection{Building "Big-Medium-Small” Three-Level Urban Public Space System}

The concept of park city advocates large-scale ecological corridor area across urban communities, with high standards of ecological greenway series urban community. Therefore, the small public space planning should consider the three scales of public space in the city, connecting the upper-level planning (the requirements of the city's large and medium-sized public spaces in the city's master plan and urban special planning and the city's relevant policy documents), enhancing the systematic of urban public space by planning and arranging small public space points on the path that connection with large and medium-sized public spaces in the city. In addition, arrange different numbers of small public spaces in residential areas with different population densities, especially increasing the number of small public spaces in high-density urban residential areas.

\subsection{Creating a City-Based Small Public Space with a Logo}

Park city transformation urban design into planning blueprint, and the most prominent way to highlight the characteristics of urban design is improving the small public space identity. Small public space can be divided into five types: community, commercial, transportation, public tour and public service. According to the characteristics of different types of urban small public space, form a set of urban small public space identification system, while integrating into the human connotation to enhance the quality of space environment. 


\subsection{Designing Reasonable Walking Paths to Enhance the Accessibility of Small Public Spaces}

Park city concept to promote green travel, so that the public calm down, slow down, close to nature, enjoy life. Such a logic requires that the design of accessibility not only takes the travel time and travel distance of residents as the standard to be measured, but also takes people's travel experience and travel perception as consideration, and then guides the flow of people that in and out of the small public space to establish a pedestrian-friendly small public space network.

\subsection{Exploring Effective Small Public Space Management Model}

The concept of park city adjusts the interesting relationship by the statutory plan. In the management of small public space planning, it should be required that the construction units should be required to specify the control requirements of small public space construction in the form of drawings, charts and text descriptions in the design results submitted for approval. In the implementation and promotion of small public space construction, focus on the small public space in the old town. The ownership of the small public space in the old town should be demarcated, so as to avoid the unmanageable and maintained space. In the construction of small public space, the fund-raising and construction incentive mechanism should be established.

\section{Planning Practice in Jiangling County, Jingzhou, Hubei Province}

Jiangling is located in the south-central part of Hubei Province, the left bank of the Jing river, section of the Yangtze River, and is attached to Jingzhou City in Hubei Province. Jiangling "land near the river", "near the state no mountains, all the mausoleum".

In recent years, Jiangling County has continuously accelerated the construction of livability in county towns and completed a series of planning and preparation work. In 2018, Jiangling County Planning Bureau organized the preparation of the Jiangling County "Urban Double Repair" Special Plan (2017-2022), which aims to complement and improve the existing planning management system, while providing an important reference for the new round of urban master planning in Jiangling County. This case selects the urban small public space part of Jiangling County's special plan for urban double repair to study.

\subsection{The Status Quo and Problems of Small Public Space in Jiangling County}

With Jiangling County center as the scope of research, the research appears to use small public space 56 places. Among them, there 7 community-type small public spaces, 2 commercial class small public spaces, 1 transport category small public spaces, 41 public tour category small public spaces, 5 public service class small public spaces. Community-type small public spaces are the residents after 
the construction of their own housing left spaces, spaces have not been designed, the ground is cement floor, but also lack of corresponding municipal facilities. Commercial small public space is a circular square enclosed by low-rise commercial buildings, single facilities and lack of landscape design, in which the psychological pleasure is low. Traffic small public space is in Jiangling station, the space is planted around the courtyard wall for a week of green planting, and the rest of the public space is cement floor, no landscape design. Public tour category small public space could be divided into belt park along the Inner Jing River, pocket park in the city area, bridgehead space in the old town three kinds of small public space, in which the inner Jing River belt park and bridgehead public space part of the space along the street are full of debris, random dumping of garbage. Some street facilities are poor, affecting the quality of space. The following image shows the distribution of pocket parks in Jiangling County (Figure 2).

\subsection{Small Public Space Planning Strategy in the Old Town of Jiangling County}

The miniature public space in the old town is part of the whole small public space system in Jiangling County. Based on the analysis of the above situation, the following strategies are proposed.

\subsubsection{Add 2 Pocket Parks}

1) Transform the negative space, form a pocket park, enrich the city's public open space level; 2) transform and upgrade the existing pocket park, improving the quality of space, clarifing the theme positioning of the pocket park in different areas, connecting the different land features around, and create a diversified art landscape space with Jiangling characteristics.
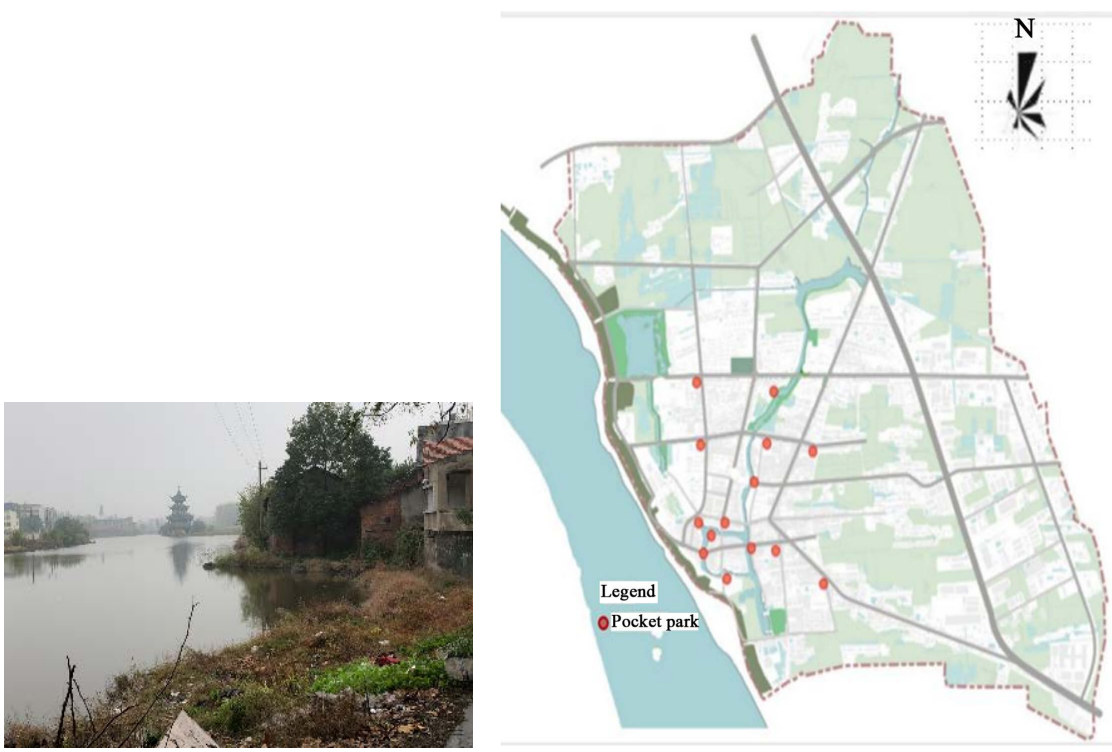

Figure 2. Distribution of pocket park in Jiangling county. 


\subsubsection{Add 4 Building Bridgehead Public Space}

1) Combine the waterfront public space system along the Inner Jing River, adding bridge; 2) establish the bridgehead public leisure space around the bridge head, enhancing the aesthetics, publicity and recognition of the bridgehead space, shaping the unique bridgehead space landscape of the water town, strengthening the connection between the bridgehead space and the waterfront space.

\section{Conclusion}

With the improvement of the development level of urban quality, the planning and construction of small public space should be paid more attention by the government and citizens. This paper analyzes the problems of urban small public space in china at present, taking the concept of park city as the theoretical guidance, studying four aspects on the construction of a complete urban public space system, the creation of a distinctive urban small public space, and the design of a reasonable walking path to enhance the accessibility of space, exploring the planning strategy of urban small public space. Hope to provide some ideas for the subsequent planning of urban small public space.

\section{Conflicts of Interest}

The authors declare no conflicts of interest regarding the publication of this paper.

\section{References}

Cao, Y. X. (2018). Exploration of the Five-Sense Experience Design Method of Urban Small Public Space. Beauty and the Times (City Edition), 10, 5-7.

Chen, S. P. (2017). Research on the Location and Chemicalization of Small Public Space in Hongshan District of Wuhan City Based on GIS. Master Thesis, Wuhan: Wuhan University.

Dong, H. X., Liu, Q., \& Wang, F. (2018). Embedding, Patching and Crowd-Regulating: Study on Urban Small Public Space Planning-Taking Wuhan Hanyang District as an Example. Urban Planning, No. 4, 33-43.

Gilbert, F. (1983). Town Design. Beijing: China Construction Industry Press.

Hillier, B. (2008). Space Is a Machine: The Theory of Building Grouping. Beijing: China Construction Industry Press.

Cullen, K. (2009). Concise Urban Landscape Design. Beijing: China Construction Industry Press.

Lynch, K. (1983). Urban Images. Beijing: Huaxia Press.

LuYuan, Y. X. (1985). External Space Design. Beijing: China Construction Industry Press.

Peng, Z. H., Ma, X. Y., Jiao, H. Z., \& Chen, W. (2018). Research on the Methods of Urban Small Public Space Planning under the Guidance of Data-Taking Wuhan Wuchang District as an Example. Modern Urban Studies, 10, 52-59.

Song, X. J., Tu, J., \& Zhou, Y. N. (2017). Urban Small Public Space System Planning and Control Strategy. Planners, 11, 72-78.

Wang, P. (2001). Systematic Construction of Urban Public Spaces. Nanjing: Southeast University Press. 